\title{
从叶内生物量分配策略的角度理解叶大小的优化
}

\author{
潘少安 ${ }^{1} \quad$ 彭国全 $^{2}$ 杨冬梅 ${ }^{*}$ \\ 1浙江师范大学化学与生命科学学院, 浙江金华 321004; ${ }^{2}$ 秦岭国家植物园, 西安 710061
}

\begin{abstract}
摘 要 叶大小的变化是许多因素综合作用的结果, 对叶大小优化机制的研究有助于我们更好地理解植物的适应进化和生 活史策略。该研究通过对浙江省清凉峰常绿阔叶混交林中的19个常绿阔叶物种和 30 个落叶阔叶物种叶水平上的相关性状进行 分析, 探讨叶内生物量分配策略对叶大小优化的限制性影响。研究结果显示: 无论叶大小用面积还是质量表示, 常绿物种和 落叶物种均呈现出叶内生物量分配到支撑结构的比例随着叶大小的增加而增加的规律, 这主要是由叶柄大小与叶片大小之 间显著的异速生长关系导致的。这种异速生长关系在常绿物种和落叶物种中普遍存在。然而, 由于常绿物种对叶柄具有较高 的机械以及抵抗冰冻栓塞等不利环境的需求, 在某一给定的叶面积下, 常绿物种比落叶物种具有更高的叶柄生物量投资。这 些结果表明: 作为整个植株支撑投资的一个重要组成部分, 叶内支撑投资所占的生物量比例对叶大小的优化具有一定的限制 性影响。
\end{abstract}

关键词 异速生长, 生物量分配, 叶片习性, 叶大小, 支撑投资

引用格式: 潘少安, 彭国全, 杨冬梅 (2015). 从叶内生物量分配策略的角度理解叶大小的优化. 植物生态学报, 39, 971-979. doi: 10.17521/cjpe.2015.0094

\section{Biomass allocation strategies within a leaf: Implication for leaf size optimization}

PAN Shao-An ${ }^{1}$, PENG Guo-Quan ${ }^{2}$, and YANG Dong-Mei ${ }^{1^{*}}$

${ }^{1}$ College of Chemistry and Life Sciences, Zhejiang Normal University, Jinhua, Zhejiang 321004, China; and ${ }^{2}$ Qinling National Botanical Garden, Xi'an, 710061, China

\section{Abstract}

Aims The variations in leaf size result from the integrated effects of many factors. Study of the mechanism to reach the optimum leaf size could help us better understand plant adaption and evolution, and plant life history strategies. Here we aim to test the hypothesis that leaf size is affected by the biomass allocation strategy within a leaf.

Methods The relationships between leaf size and different biomass partitioning patterns within a leaf were studied for 19 evergreen and 30 deciduous broadleaved woody species from Qingliang Mountain, Zhejiang, China. The standardized major axis estimation method was used to examine the scaling relationship between lamina size and petiole size within a leaf. The relationship between leaf size and support investment ratio within a leaf was estimated by the Model Type I regression analysis.

Important findings Biomass allocation in petiole increased with leaf size similarly in both evergreen and deciduous leaves, which resulted from the significant allometric scaling relationship between petiole mass and lamina mass (and area) with slopes significantly larger than 1.0, independent of leaf habit. However, evergreen species were found to have a greater petiole mass at a given lamina mass or area than deciduous species, which may be due to their higher demand for mechanic support and resistance to freezing-induced embolism in petioles. Results suggest that leaf size could be affected by the fraction of support investment within a leaf.

Key words allometric scaling, biomass allocation, leaf habit, leaf size, support investments

Citation: Pan SA, Peng GQ, Yang DM (2015). Biomass allocation strategies within a leaf: implication for leaf size optimization. Chinese Journal of Plant Ecology, 39, 971-979. doi: 10.17521/cjpe.2015.0094

大小是植物体最重要的变化性状 (Price \& Weitz, 2012)。单个叶作为植物功能性状的基本单元,
其大小在物种间，无论是环境梯度上还是群落内部 都表现出极大的可塑性, 在全球范围内其变化幅度

收稿日期Received: 2015-03-23 接受日期Accepted: 2015-08-13

* 通讯作者Author for correspondence (E-mail: yangdm@zjnu.cn) 
达到6个数量级(Milla \& Reich, 2007)。叶大小不仅决 定了植物对光的拦截效率和碳获取能力, 直接影响 植物生产力的大小和对生存环境的适应能力, 而且 也决定了植物的竞争能力(Castro-Díez et al., 2000)。

叶大小的变化是许多因素综合作用的结果。现 有的研究表明: 叶大小的变化既与植物所处生境中 的养分和水分有效性(Givnish, 1987; Niinemets \& Kull, 1994; Roth-Nebelsick et al., 2001)、温度 (Givnish, 1984; McDonald et al., 2003; 杨冬梅等, 2012)、光照(Bragg \& Westoby, 2002; McDonald et al., 2003)等环境因素有关, 也与植物体自身的其他 功能性状, 如单位叶面积上的干质量和光合能力 (Milla \& Reich, 2007; Niklas et al., 2007)、植株高度 (Ackerly \& Donoghue, 1998; Cornelissen, 1999)、支 撑枝条或小枝的大小(Westoby \& Wright, 2003; Sun et al., 2006; Yang et al., 2010)等密切相关。因此, 长 期以来许多生态学家从叶大小与气候、植物其他功 能性状的关系以及植物的生长代谢等不同角度提出 了多个关于叶大小优化的变化关系和理论模型, 并 对其形成机制和适应价值进行了预测和解释。如 Corner法则提出小枝越大叶越大(Corner, 1949); 光 合作用模型认为叶大小的形成是适应叶片温度调节 的结果, 使叶片温度控制在光合作用的最适温度范 围附近(Taylor \& Sexton, 1972; Taylor, 1975); 水分 利用效率模型则认为叶大小的优化目标是使叶片的 净光合速率与水分丢失的比值(即水分利用效率)达 到最大(Parkhurst \& Loucks, 1972)等, 这些研究增进 了我们对叶大小适应进化的理解。

然而, 作为研究的主体, 叶自身的生物量投资 分配关系对叶大小优化的影响很少被专门进行研 究。一个完整的叶通常由两部分组成, 即一个展开 的直接用于光合作用的叶片 (lamina)和一个悬臂结 构、起支撑和输导作用的叶柄(petiole)。一般而言, 在叶的总生物量一定的情况下, 分配给叶片的生物 量越多, 叶的光合碳获取能力越强, 对植物越有利。 然而, 大叶通常要遭受更大的拉拽力, 叶片面积和 质量的增加也要求叶柄具有更高的支撑能力 (Pearcy \& Yang, 1998; Niklas, 1999; 祝介东等, 2011), 同时, 叶片面积的增加也需要更长的叶柄来 减少个体内部对光的相互遮挡(Takenaka, 1994; 祝 介东等, 2011), 并且大叶还需要叶柄具有更强的水 分输导能力以满足其蒸腾需要, 所以大叶需要对叶
柄的生物量投资增加。因此我们预测, 在单叶水平 上，对叶柄的生物量投资比例将有可能限制叶大小 的变化, 并且随着叶大小的增加, 叶增大获得的收 益有可能被所需增加的叶柄支撑成本抵消甚至超 出, 即叶内的支撑投资将随着叶大小的增加而递 增。在叶水平内的生物量分配即使在相同的群落内, 也可能因不同的植物叶习性(常绿和落叶)而有差 异。常绿物种与落叶物种在叶特征上有很大的差异, 比如具有高的比叶重、长的叶寿命、低的养分含量 和低的光合速率(Reich et al., 1992; Westoby et al., 2002; Wright et al., 2004)。叶柄不仅是叶片的支撑结 构, 同时还行使为叶片输送水分的功能。与落叶物 种相比, 常绿物种叶片在冬季不调落, 经受不利生 长环境的时间更长。为了在不利环境下确保叶片的 水分运输安全, 常绿物种通常比落叶物种需具有更 强的抵抗冰冻或干旱引起的栓塞的能力(Cavender-

Bares \& Holbrook, 2001; Cavender-Bares et al., 2005), 这将有可能导致常绿物种对叶柄的投资比 例增加。

本研究以叶面积、叶鲜质量和叶干质量表征叶 大小, 通过分析清凉峰常绿阔叶混交林带19个常绿 阔叶物种和 30 个落叶阔叶物种叶水平上的相关特 征, 探讨叶水平上的生物量分配关系对叶大小变化 的影响, 及其在两类不同生活型物种间的差异。

\section{1 材料和方法}

\section{1 样地情况}

样地位于浙江省清凉峰自然保护区 $\left(118.87^{\circ}\right.$ $\left.119.18^{\circ} \mathrm{N}, 30.08^{\circ}-30.28^{\circ} \mathrm{E}\right)$, 主峰海拔1 $787.4 \mathrm{~m}$, 属 亚热带湿润季风气候。保护区植被属于我国东部中 亚热带常绿阔叶林北部亚地带, 植被垂直变化规律 明显, 植被带随海拔梯度在气候、土壤和植被的变 化见宋朝枢(1997)、钱宏和汪思龙(1988)、黄成林 (1992)、杨冬梅等(2012)等文献。

本研究物种位于保护区常绿-落叶阔叶混交林 带(海拔700-1 200 m)。此地年降水量达1 500-1900 $\mathrm{mm}$, 海拔 800 和 $1100 \mathrm{~m}$ 处, 7月和年平均气温分别 为 $24.1{ }^{\circ} \mathrm{C}$ 和 $12.5{ }^{\circ} \mathrm{C} 、 22.5{ }^{\circ} \mathrm{C}$ 和 $11.1{ }^{\circ} \mathrm{C}$ (宋朝枢, 1997)。土壤类型为山地黄壤和山地棕壤。

\section{2 植物采样}

2011年7-8月, 当小枝生长和展叶完成时, 在常 绿-落叶阔叶混交林带采集 30 个落叶阔叶物种和 19 
个常绿阔叶物种, 共 49 个物种, 属于 17 科 23 属。对每 一个所研究的物种随机选取 3-5个个体, 且在植物 外冠层对每个个体随机选取没有明显叶面积损失的 3-5个当年生末端小枝, 即从最末端到最后一个末 梢分枝处，通常为不分支，且无花和果实。小枝上的 叶由执行光合功能的叶片和行使支撑功能的叶柄两 部分构成。以小枝为单位, 记录叶片面积(通过扫描 叶片, 并用MapInfo软件进行计算)、叶数量、叶片 鲜质量、叶柄鲜质量等。将叶片、叶柄分别在 $70{ }^{\circ} \mathrm{C}$ 烘箱中烘干 $48 \mathrm{~h}$ 至恒定质量, 并记录干质量。本文用 单叶叶面积、单叶干质量和单叶鲜质量来表征叶大 小。用叶柄所占总叶干质量的比例来表征叶内支撑 投资的生物量分配比例。本文中若无特殊说明，叶 干质量、叶鲜质量、叶柄干质量及叶片面积均以单 个叶为单位。

\section{3 数据分析}

对植物功能性状先计算个体上的算术平均值, 再计算种内平均值, 最后以物种平均值进行分析。 叶片与叶柄两个功能性状间的关系用方程 $y=b x^{a}$ 来描述, 线性转换为 $\log (y)=\log (b)+a \log (x)$, 其中 $x$ 和 $y$ 分别表示两个功能性状, 线性关系中, $\log (b)$ 表 示性状关系的截距, $a$ 表示斜率, $a=1$ 时为等速生长, 大于或小于1时为异速生长(Harvey \& Pagel, 1991)。 异速生长方程的参数估计采用标准化主轴估计 (SMA)方法(Warton et al., 2006), 由软件(S)MATR Version 2.0 (Falster et al., 2006)计算完成。回归斜率 的置信区间根据文献(Pitman, 1939)记载的方法计 算。对常绿和落叶物种组的斜率采用Warton和Weber (2002)的方法进行异质性检验, 如果检验结果没有 异质性 $(p>0.05)$, 就给出一个共同斜率。截距差异 ( $y$ 轴上的差异)通过比较两类物种组 $y$ 轴代表的某一 叶属性平均值相对于共同斜率主轴的位移而得到, 沿共同主轴方向的位移与之类似。SMA方法已广泛 应用于植物体内任意两个功能性状间的异速生长或
等速生长关系的相关研究中(Wright et al., 2002; Westoby \& Wright, 2003; Sun et al., 2006; Li et al., 2008; Yang et al., 2009, 2010)。

常绿和落叶物种组的功能性状间的比较采用独 立样本的 $t$ 检验; 叶柄生物量分配比例与叶大小间 的关系采用直线回归分析 (即最小二乘法); 对于常 绿物种和落叶物种组的回归关系斜率的差异性采用 协方差分析(ANCOVA), 当分组变量 $\times$ 协变量(回归 分析中的自变量)的交互作用项在统计上不显著 $(p>$ 0.05)时, 表明两组回归斜率无显著差异, 此时将继 续进行共同斜率下的截距差异性分析 (Sokal \& Rohlf, 1995)。所有数据分析均在SPSS 18.0 (SPSS, Chicago, USA)下进行。

\section{2 结果}

\section{1 叶柄生物量分配比例与叶大小的关系}

在本研究中, 叶内支撑结构的生物量投资比例 (叶柄干质量与总叶生物量之比)在不同物种间具有 很大的变异。在落叶物种中, 单位叶的叶柄生物量 分配比例从 0.019 到 $0.140 \mathrm{~g} \cdot \mathrm{g}^{-1}$, 平均值 $0.055 \mathrm{~g} \cdot \mathrm{g}^{-1}$, 而常绿物种中, 该比值变化从 0.027 到 $0.175 \mathrm{~g} \cdot \mathrm{g}^{-1}$, 平均值 $0.056 \mathrm{~g} \cdot \mathrm{g}^{-1}$ 。叶柄与叶片生物量比例关系与此 相似(表1)。叶柄生物量分配比例在常绿物种和落叶 物种之间无显著差异，同样，叶干质量、叶鲜质量的 总体平均值在两类物种组间均无显著差异, 但落叶 物种的平均叶片面积显著大于常绿物种(表1)。

叶柄生物量分配比例与叶大小具有极显著的正 相关关系(所有的 $p$ 值均小于 0.001 )。在常绿和落叶物 种组中, 叶柄生物量分配比例随着叶片面积(图 $1 \mathrm{~A})$ 、叶鲜质量(图1B)和叶干质量(图1C)的增加而增 加, 并且两者的相关性在常绿物种组比落叶物种组 更显著(图1)。由于叶片面积、叶鲜质量和叶干质量 三者之间存在着极为显著的正相关关系 $(p<0.001)$, 叶柄生物量分配比例与这3种表征叶大小的指标具

表1 清凉峰不同功能组物种的叶功能特征(平均值土标准误差)

Table 1 Leaf functional traits of different functional groups in Qingliang Mountain (mean $\pm S E$ )

\begin{tabular}{lccccc}
\hline $\begin{array}{l}\text { 功能组 } \\
\text { Functional group }\end{array}$ & $\begin{array}{c}\text { 样本量 } \\
\text { No. of samples }\end{array}$ & $\begin{array}{c}\text { 叶面积 } \\
\text { Leaf area }\left(\mathrm{cm}^{2}\right)\end{array}$ & $\begin{array}{c}\text { 叶鲜质量 } \\
\text { Leaf fresh mass (g) }\end{array}$ & $\begin{array}{c}\text { 叶干质量 } \\
\text { Leaf dry mass (g) }\end{array}$ & $\begin{array}{c}\text { 叶柄/叶片干质量 } \\
\text { Petiole/lamina } \\
\text { dry mass ratio }\end{array}$ \\
\hline 落叶 Deciduous & 30 & $31.351 \pm 3.634^{\mathrm{b}}$ & $0.430 \pm 0.051$ & $0.156 \pm 0.019$ & $0.059 \pm 0.006$ \\
常绿 Evergreen & 19 & $19.783 \pm 3.526^{\mathrm{a}}$ & $0.443 \pm 0.087$ & $0.167 \pm 0.024$ & $0.061 \pm 0.009$ \\
\hline
\end{tabular}

在同一列, 不同字母表示常绿物种与落叶物种组进行 $t$ 检验时, 结果具有显著差异 $(p<0.05)$ 。

Different letters indicate significant difference by $t$-test $(p<0.05)$. 

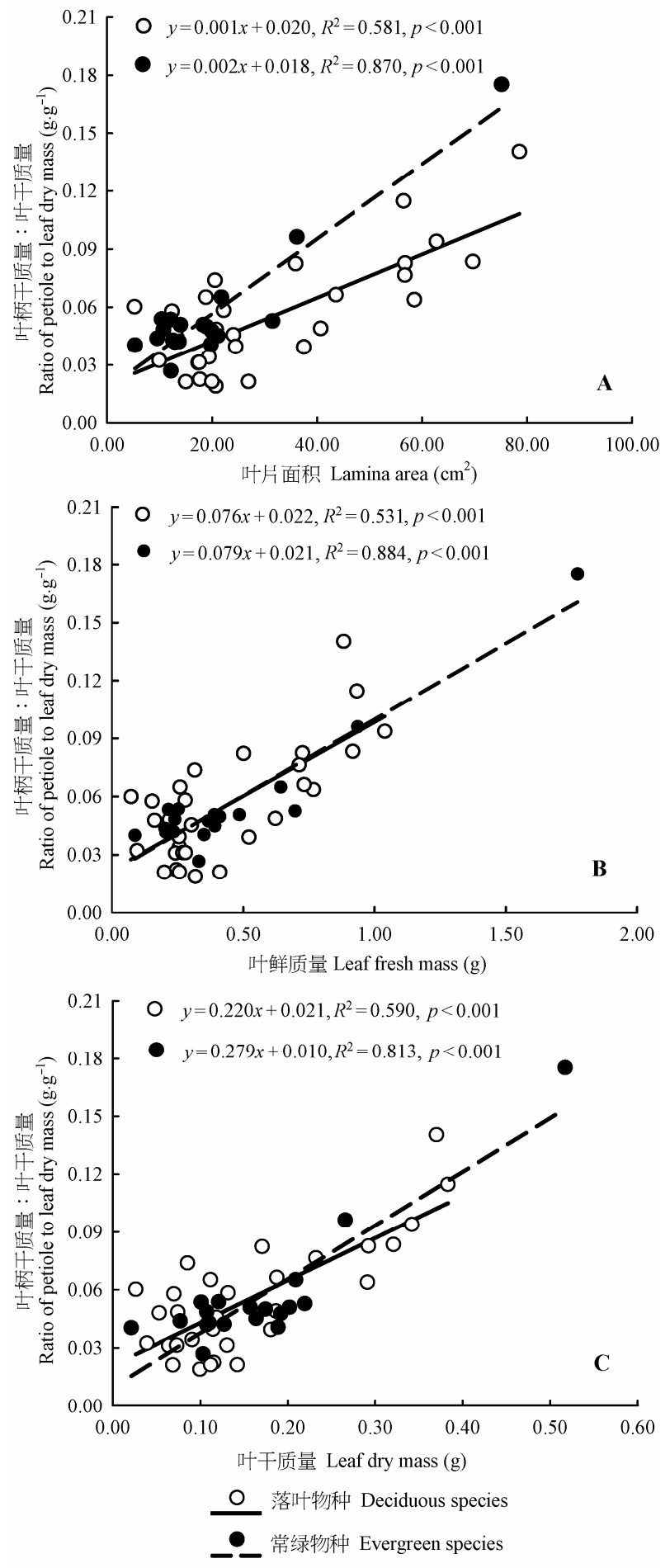

图1 叶柄在叶中的生物量分配比例与叶片面积(A)、叶鲜质 量(B)和叶干质量 $(\mathbf{C})$ 的关系。

Fig. 1 Relationships between petiole/leaf dry mass ratio and lamina area (A), leaf fresh mass (B) and leaf dry mass (C).

有等同的相关关系，叶柄生物量分配比例所能解释 的叶大小的变化相似, 如常绿物种的决定系数 $R^{2}$ 从 0.813 到 0.884 , 落叶物种 $R^{2}$ 从 0.531 到 0.590 (图1)。
根据协方差分析，在叶柄生物量分配比例与叶 大小的相关关系中，当叶大小用叶干质量和叶鲜质 量表示时，常绿物种和落叶物种组斜率均无显著差 异(图1B, 1C, $p$ 等于 0.247 和0.880); 在相同的叶干质 量或叶鲜质量下, 截距也无显著差异 $(p$ 等于 0.764 和 0.991), 这些结果表明, 叶柄生物量分配比例对叶 干质量和叶鲜质量的影响在常绿和落叶物种组间是 相同的。

然而, 叶柄生物量分配比例与叶片面积的回归 关系中，常绿物种组的斜率显著高于落叶物种组 (图1A, $p=0.01$ ), 表明在叶片面积变化相同的情况 下，常绿物种对叶柄的投资变化比落叶物种更 显著。

\section{2 叶柄干质量与叶大小的关系}

叶柄干质量与叶片面积在常绿和落叶物种组中 均具有显著的正相关关系(表 2), 其共同斜率为 0.614 ( $p=0.839,95 \%$ 置信区间0.542-0.687, 图2A), 显著小于 $1(p<0.001)$, 表明叶柄干质量与叶片面积 具有显著的异速生长关系, 且叶柄的增加速度较叶 片面积增加的快。此外, 落叶物种叶柄干质量与叶 片面积的共同斜率的 $y$ 轴截距显著大于常绿物种组 (图2A, $p<0.001$ ), 表明在某一给定的叶柄干质量 时, 落叶物种比常绿物种具有更大的叶片面积。

叶柄干质量与叶片干质量在常绿和落叶物种组 中同样具有显著的正相关关系(表2), 两个物种组的 共同斜率为 $0.637(p=0.566,95 \%$ 置信区间 $0.562-0.720$, 图2B), 显著小于 $1(p<0.001)$, 表明叶 柄干质量与叶片干质量具有显著的异速生长关系, 且叶柄干质量的增加速度较叶片干质量增加得快。

\section{3 讨论}

\section{1 叶内支撑投资成本是叶大小变化的限制性因} 素之一

生物量分配是整个植株净碳获取的重要驱动因 子(Körner, 1991)。植株生长速率与叶生物量比例成 正相关，与支撑结构的生物量比例成负相关(Reich, 1998; Wright \& Westoby, 2001)。叶内支撑投资所占 的生物量比例是整个植株支撑投资的一个重要组分 (Givnish, 1984; Niinemets \& Kull, 1999; Niinemets et $a l ., 2006)$, 然而这些支撑成本仅在一小部分的物种 中进行过估测(Givnish, 1984; Niklas, 1993; Niinemets et al., 2006; Niinemets \& Sack, 2006; Li 
表2 清凉峰阔叶木本植物叶大小与叶支撑结构的标准化主轴估计回归关系(回归关系均达到极显著水平, $p<0.001$ )

Table 2 Relationships between leaf size and leaf biomass of supporting organs of woody species in Qingliang Mountain using standardized major axis (SMA) regression. All scaling relationships were highly significant $(p<0.001)$

\begin{tabular}{llccc}
\hline $\begin{array}{l}\text { 指标 }(y \text { 轴- } x \text { 轴 }) \\
\text { Index }(y \text {-axis- } x \text {-axis) }\end{array}$ & $\begin{array}{l}\text { 功能组 } \\
\text { Functional group }\end{array}$ & $\begin{array}{c}\text { 样本量 } \\
\text { No. of samples }\end{array}$ & $\begin{array}{c}\text { 斜率(95\%置信区间) } \\
\text { Coefficient of determination }\end{array}$ & $\begin{array}{c}\text { Slope (95\% confidence interval) } \\
\text { 叶面积-叶柄干质量 }\end{array}$ \\
Leaf area - petiole dry mass & 落叶 Deciduous & 30 & 0.805 & $0.603(0.509,0.715)$ \\
& 常绿 Evergreen & 19 & 0.883 & $0.617(0.519,0.735)$ \\
叶片干质量-叶柄干质量 & 落叶 Deciduous & 30 & 0.794 & $0.615(0.516,0.732)$ \\
Lamina dry mass - petiole dry mass & 常绿 Evergreen & 19 & 0.876 & $0.659(0.551,0.788)$ \\
\hline
\end{tabular}
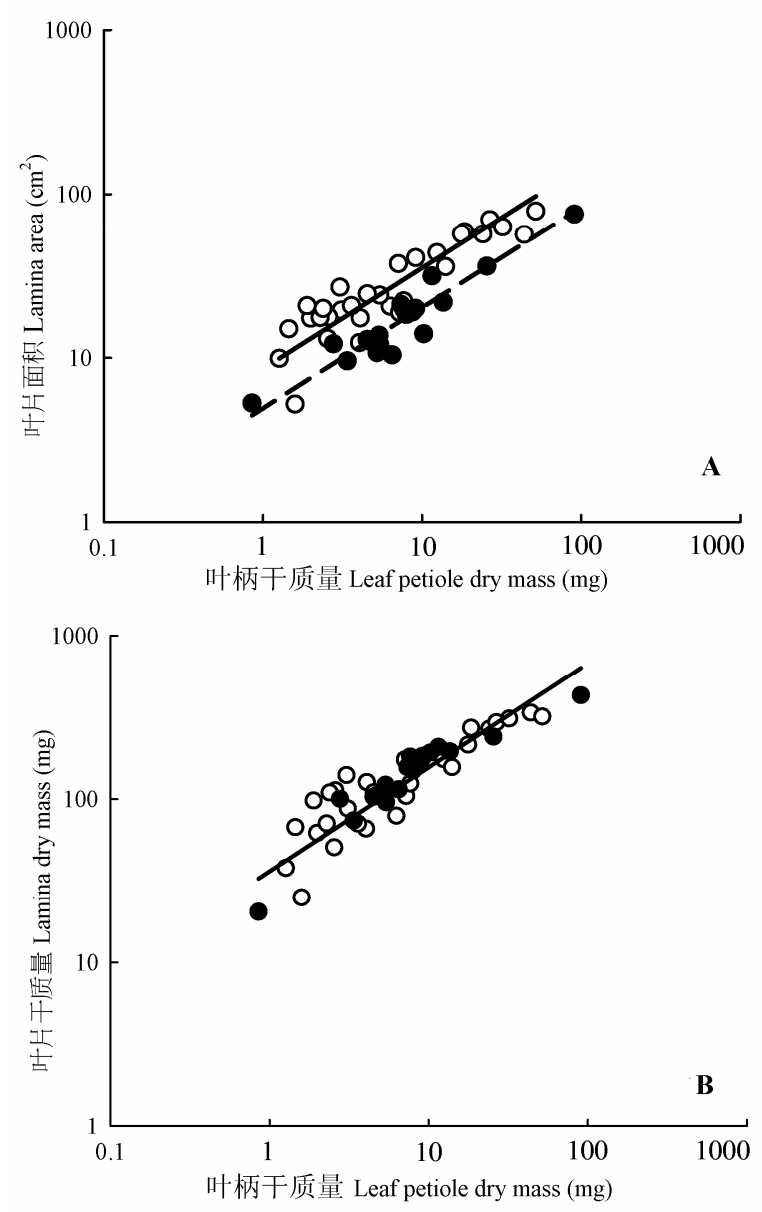

O 落叶物种 Deciduous species
— 常绿物种 Evergreen species

图2 叶柄干质量与叶片面积(A)、叶片干质量 $(\mathbf{B})$ 之间的关 系。

Fig. 2 Cross-species relationships between leaf petiole dry mass and lamina area (A) and lamina dry mass (B).

et al., 2008)。以前的大多数相关研究表明, 叶柄占 整个叶生物量的比例约为 0.02 到 $0.30 \mathrm{~g} \cdot \mathrm{g}^{-1}$ (Cao \& Ohkubo, 1998; Niinemets, 1998; Niinemets \& Kull, 1999), 本研究的结果与之相似。在我们的研究中, 叶柄生物量分配比例变化区间为 0.019 到 0.175 $\mathrm{g} \cdot \mathrm{g}^{-1}$ 。但在Niinemets等(2006)的研究中, 最大叶物种 中的叶柄生物量占整个叶干质量的比例达到 0.70 $\mathrm{g} \cdot \mathrm{g}^{-1}$, 与多数研究及本研究的结果相差较大, 这可 能是由于生境、物种种类及叶形态的不同导致的。

本研究发现, 无论是常绿物种还是落叶物种, 在叶内叶柄生物量分配比例都与叶大小成很好的正 相关关系(图1)。当用叶干质量和叶鲜质量表征叶大 小时, 叶柄生物量分配比例与叶大小之间的回归关 系斜率在常绿物种和落叶物种中相同, 表明在单位 叶干质量或鲜质量的基础上, 常绿物种和落叶物种 具有相同的叶内支撑投资比例(图1B, 1C)。这一结果 与Niinemets等(2006)对单叶和复叶物种的研究结果 相一致。但是, 当用叶片面积表征叶大小时, 常绿物 种组中的叶柄生物量分配比例与叶大小的回归关系 斜率大于落叶物种组, 表明在叶片面积变化相同的 情况下, 常绿物种的叶内支撑投资的变化比落叶物 种更大(图1A)。这些结果都表明, 在叶水平上, 叶内 支撑投资比例对叶大小的变化具有决定性的作用, 支撑投资将随着叶大小的增加而呈成本加速递增的 趋势, 叶增大所需要增加的支撑成本有可能会抵消 甚至高于因叶增大所增加的碳收益。所以, 对植物 而言, 并不一定总是叶越大越有利, 大叶物种并不 一定比小叶物种更有优势。在我们以前从小枝水平 上对温带木本植物的研究中, 也发现在某一给定的 茎投资(茎干质量)下，大叶或大枝物种并不比小叶、 小枝物种在展叶效率方面更有优势(Yang et al., 2009)。但是Pickup等(2005)对小枝水平上的生物量 分配关系进行研究发现: 在小枝水平上, 大叶物种 在单位茎木质部横截面积基础上具有更多的叶生物 量分配, Niinemets等(2006)的研究得到了类似的研 究结果。他们认为在相同的单位茎生物量投资的基 础上, 大叶物种将具有更强的碳获取能力, 因而在 自然界中将更有优势, 本研究结论与之不一致。在 今后的研究中, 还需对整个植株内的生物量投资分 
配关系进行综合研究, 进一步论证大叶物种在小枝 水平上更大的叶生物量分配优势是否会被其更大的 叶内支撑投资所抵消, 从而证明大叶物种是否比小 叶物种更有优势。

此外, 本研究还发现, 在叶内, 支撑结构叶柄 干质量与光合结构叶片大小具有显著的异速生长关 系(图2), 该结果与以前的相关研究结果(Niinemets et al., 2006, 2007; Li et al., 2008; 杨冬梅等, 2012)一 致。支撑结构和光合结构间的异速生长关系, 可以 由“管道模型(pipe model)”理论进行解释。该理论认 为: 输导组织的横截面积应与其上的叶面积成等比 例, 但是叶柄作为叶内的支撑结构, 除了具有传输 水分等功能外, 还需要行使支撑整个叶的静态重力 和抵抗外界动态拉力的作用, 需要为叶片提供额外 的机械支撑, 导致在叶水平上, 叶柄与叶片间存在 异速生长关系。这种叶片和叶柄不成比例的增长方 式, 进一步证明了叶内支撑投资随叶大小的增加而 增加的速度比叶大小本身的增加速度更快, 也就是 说, 植物为增加叶大小所付出的代价有可能比其所 获得收益要更大, 这对植物而言是极为不利的。因 此, 在叶水平上, 对叶柄的支撑投资有可能是限制 叶大小优化的因素之一。

\section{2 常绿物种和落叶物种的比较}

在本研究中, 当叶大小用叶质量(干质量和鲜 质量)表示时, 其与叶柄生物量分配比例之间的相 关关系在常绿物种组和落叶物种组间无显著差异 (斜率和截距均无显著差异), 因为无论是叶柄生物 量分配比例还是叶质量在两个物种组间均无显著差 异。而在叶片面积与叶柄生物量分配比例的相关关 系中, 常绿物种组的斜率显著高于落叶物种组。这 是由于一方面常绿物种的叶片面积显著小于落叶物 种所引起; 另一方面常绿物种单位叶柄生物量投资 所能支撑的叶片面积比落叶物种更小, 两者共同导 致常绿物种的叶柄生物量分配比例对叶大小变化的 反应比落叶物种更加敏感, 常绿物种中的叶柄生物 量分配比例随叶大小增加而增加的速度比落叶物种 更快。这是因为叶柄除了作为支撑结构为叶片提供 机械支撑外, 还兼具为叶片输送水分的功能。常绿 物种一年四季均有叶片存在, 即便是在冬季等不利 生长季节也不落叶, 要确保在冬季低温等极端环境 下的水分运输安全, 常绿物种叶柄中的导管必须要 有较强的抗低温及冰冻栓塞的能力。因此, 常绿物
种叶柄中的导管直径通常较小 (Cavender-Bares \& Holbrook, 2001; Cavender-Bares et al., 2005), 由此 导致其叶柄的水分运输效率不高, 在某一给定的叶 柄投资下, 常绿物种比落叶物种具有更小的叶片面 积(Li et al., 2008)。

\section{3 叶大小优化与叶内支撑投资之间关系的生态 学意义}

在木本乔木和灌木中, 大叶被认为是一种应对 低光环境的生态学策略。因为大叶能够平铺排布, 有效地捕获来自垂直角度的光和大部分的光斑 (Horn, 1971)。与此一致的是, 处于演替后期的温带 森林的林下木本植物往往是大叶物种(Niinemets \& Kull, 1994)。然而, 从支撑成本的角度看, 大叶物种 较小的叶间隙的代价是比较高的, 因为它们需要增 强枝条、茎和叶柄构建, 增加对支撑结构的生物量 投资。通过延长枝条、茎和叶柄的总长度, 可以减 少叶片之间的相互遮荫, 有效地提高叶片的光拦截 效率(Brites \& Valladares, 2005; Pearcy et al., 2005)。 但是在热带, 快速生长的先锋物种具有较快的叶周 转率, 经常看到大叶连接在杆状的茎上(Tomlinson, 1987), 表明大叶、大量的分枝和快速的叶周转率是 不可能同时出现的。而Valladares等(2002)指出, 叶 内与茎内支撑投资之间可能存在某种权衡关系, 进 而导致不同的冠层设计, 使得捕光效率在总体上是 相似的。所以是否大叶物种一定需要更大的茎内投 资，是否叶内与茎内支撑投资之间具有一定的限制 性关系, 需要在未来的研究中进一步验证。很遗憾, 本研究未对茎水平上的支撑投资进行研究, 但是至 少在叶水平上, 叶大小的增加不可避免地会造成叶 内支撑成本不成比例的增加。

小叶和大叶之间另一个重要的差异是对草食性 动物破坏的抵抗能力不一样。Moles 和 Westoby (2000)观察到小叶物种可以在较短的时间内迅速完 成展叶, 展叶完成后, 叶片对草食性动物的可口性 下降, 从而减少其受草食性动物攻击的机会。在总 的叶生物量一定的情况下, 构建许多小叶或分裂成 小裂叶, 也能够减轻对小叶突发性损伤造成的损失, 增强植株对意外伤害的抵抗能力。

总之, 植物叶是由悬臂结构叶柄和行使光合作 用的叶片两部分组成, 叶生物量在叶柄和叶片之间 的分配对于理解叶大小的优化具有重要意义。我们 的研究结果表明, 无论是在常绿物种还是在落叶物 
种中, 叶柄的支撑投资占总叶生物量的比例最高达 到18\%, 并且叶柄干质量与叶片大小之间是比例指 数大于 1 的异速生长关系, 表明随着叶大小的增加, 对叶柄的支撑投资也将不成比例地增加, 叶大小增 加所获得的收益并不一定能弥补随之而来的叶柄支 撑成本的增加。所以, 并不是叶越大对植物越有利, 至少在叶水平上, 大叶物种并不比小叶物种更有优 势。因此, 叶水平上的生物量分配策略也是植物叶 大小优化的内在因素之一, 并将限制叶大小的变 化。

\section{基金项目 国家自然科学基金(31000193)。}

致谢 浙江省清凉峰自然保护区张宏伟工程师、浙 江师范大学化学与生命科学学院陈建华教授为本研 究中的物种鉴定提供了大量的帮助; 在研究过程 中, 得到了浙江师范大学行知学院章佳佳、钱敏杰、 郑瑶、周丹和金灵妙等同学的大力协助; 浙江省清 凉峰自然保护区为本研究的野外采样提供了便利条 件, 在此一并致谢。

\section{参考文献}

Ackerly DD, Donoghue MJ (1998). Leaf size, sapling allometry, and Corner's rules: Phylogeny and correlated evolution in maples (Acer). The American Naturalist, 152, 767791.

Bragg JG, Westoby M (2002). Leaf size and foraging for light in a sclerophyll woodland. Functional Ecology, 16, 633-639.

Brites D, Valladares F (2005). Implications of opposite phyllotaxis for light interception efficiency of Mediterranean woody plants. Trees, 19, 671-679.

Cao KF, Ohkubo T (1998). Allometry, root/shoot ratio and root architecture in understory saplings of deciduous dicotyledonous trees in central Japan. Ecological Research, 13, 217-227.

Castro-Díez P, Puyravaud JP, Cornelissen JHC (2000). Leaf structure and anatomy as related to leaf mass per area variation in seedlings of a wide range of woody plant species and types. Oecologia, 124, 476-486.

Cavender-Bares J, Cortes P, Rambal S, Joffre R, Miles B, Rocheteau A (2005). Summer and winter sensitivity of leaves and xylem to minimum freezing temperatures: A comparison of co-occurring Mediterranean oaks that differ in leaf lifespan. New Phytologist, 168, 597-612.

Cavender-Bares J, Holbrook NM (2001). Hydraulic properties and freezing-induced cavitation in sympatric evergreen and deciduous oaks with contrasting habitats. Plant, Cell \& Environment, 24, 1243-1256.
Cornelissen JHC (1999). A triangular relationship between leaf size and seed size among woody species: Allometry, ontogeny, ecology and taxonomy. Oecologia, 118, 248-255.

Corner EJH (1949). The durian theory or the origin of the modern tree. Annals of Botany, 13, 367-414.

Falster DS, Warton DI, Wright IJ (2006). User's guide to SMATR: Standardised major axis tests and routines version 2.0. http://www.bio.mq.edu.au/ecology/SMATR. Cited: 11 March 2015

Givnish TJ (1984). Leaf and canopy adaptations in tropical forests. In: Medina E, Mooney HA, Vasquez-Yanes C eds. Physiological Ecology of Plants of the Wet Tropics. Springer, Berlin. 51-84.

Givnish TJ (1987). Comparative studies of leaf form: Assessing the relative roles of selective pressures and phylogenetic constraints. The New Phytologist, 106, 131-160.

Harvey PH, Pagel MD (1991). The Comparative Method in Evolutionary Biology. Oxford University Press, Oxford, UK. 239.

Horn HS (1971). The Adaptive Geometry of Trees (Vol. 3). Princeton University Press, Princeton, USA.

Huang CL (1992). Florogeographical analysis of Mount Qingliangfeng Natural Reserve in Tianmu Mountains. Journal of Zhejiang Forestry College, 9, 277-282. (in Chinese with English abstract) [黄成林 (1992). 天目山 清凉峰自然保护区植物区系地理分析. 浙江林学院学 报, 9, 277-282.]

Körner C (1991). Some often overlooked plant characteristics as determinants of plant growth: A reconsideration. Functional Ecology, 5, 162-173.

Li GY, Yang DM, Sun SC (2008). Allometric relationships between lamina area, lamina mass and petiole mass of 93 temperate woody species vary with leaf habit, leaf form and altitude. Functional Ecology, 22, 557-564.

McDonald PG, Fonseca CR, Overton JM, Westoby M (2003). Leaf-size divergence along rainfall and soil-nutrient gradients: Is the method of size reduction common among clades? Functional Ecology, 17, 50-57.

Milla R, Reich PB (2007). The scaling of leaf area and mass: The cost of light interception increases with leaf size. Proceedings of the Royal Society B: Biological Sciences, 274, 2109-2115.

Moles AT, Westoby M (2000). Do small leaves expand faster than large leaves, and do shorter expansion times reduce herbivore damage? Oikos, 90, 517-524.

Niinemets Ü (1998). Are compound-leaved woody species inherently shade-intolerant? An analysis of species ecological requirements and foliar support costs. Plant Ecology, 134, 1-11.

Niinemets Ü, Kull K (1994). Leaf weight per area and leaf size 
of 85 Estonian woody species in relation to shade tolerance and light availability. Forest Ecology and Management, 70, 1-10.

Niinemets Ü, Kull O (1999). Biomass investment in leaf lamina versus lamina support in relation to growth irradiance and leaf size in temperate deciduous trees. Tree Physiology, 19, 349-358.

Niinemets Ü, Portsmuth A, Tobias M (2006). Leaf size modifies support biomass distribution among stems, petioles and mid-ribs in temperate plants. New Phytologist, 171, 91-104.

Niinemets Ü, Portsmuth A, Tobias M (2007). Leaf shape and venation pattern alter the support investments within leaf lamina in temperate species: A neglected source of leaf physiological differentiation? Functional Ecology, 21, 28-40.

Niinemets Ü, Sack L (2006). Structural determinants of leaf light-harvesting capacity and photosynthetic potentials. In: Esser K, Lüttge U, Beyschlag W, Murata J eds. Progress in Botany. Springer, Berlin. 385-419.

Niklas KJ (1993). Testing “economy in design” in plants: Are the petioles and rachises of leaves "designed" according to the principle of uniform strength? Annals of Botany, 71, 33-41.

Niklas KJ (1999). A mechanical perspective on foliage leaf form and function. New Phytologist, 143, 19-31.

Niklas KJ, Cobb ED, Niinemets Ü, Reich PB, Sellin A, Shipley B, Wright IJ (2007). "Diminishing returns" in the scaling of functional leaf traits across and within species groups. Proceedings of the National Academy of Sciences of the United States of America, 104, 8891-8896.

Parkhurst DF, Loucks OL (1972). Optimal leaf size in relation to environment. The Journal of Ecology, 60, 505-537.

Pearcy RW, Yang W (1998). The functional morphology of light capture and carbon gain in the Redwood forest understorey plant Adenocaulon bicolor Hook. Functional Ecology, 12, 543-552.

Pearcy RW, Muraoka H, Valladares F (2005). Crown architecture in sun and shade environments: Assessing function and trade-offs with a three-dimensional simulation model. New Phytologist, 166, 791-800.

Pickup M, Westoby M, Basden A (2005). Dry mass costs of deploying leaf area in relation to leaf size. Functional Ecology, 19, 88-97.

Pitman E (1939). A note on normal correlation. Biometrika, 31, 9-12.

Price CA, Weitz JS (2012). Allometric covariation: A hallmark behavior of plants and leaves. New Phytologist, 193, 882-889.

Qian H, Wang SL (1988). Major forest vegetation types and their distributions in Qingliang Mountain Natural Reserve (JQNR) of Jixi County, Anhui Province. Journal of Ecology, 7(2), 32-36. (in Chinese with English abstract) [钱宏, 汪思龙 (1988). 安徽省绩溪县清凉峰自然保护区主要 森林植被类型及其分布. 生态学杂志, 7(2), 32-36.]

Reich PB, Walters MB, Ellsworth DS (1992). Leaf life-span in relation to leaf, plant, and stand characteristics among diverse ecosystems. Ecological Monographs, 62, 365-392.

Reich PB (1998). Variation among plant species in leaf turnover rates and associated traits: Implications for growth at all lefe stages. In: Lambers H, Poorter H, van Vuuren MMI eds. Inherent Variation in Plant Growth. Physiological Mechanisms and Ecological Consequences. Backuys Publishers, Leiden, The Netherlands. 467-487.

Roth-Nebelsick A, Uhl D, Mosbrugger V, Kerp H (2001). Evolution and function of leaf venation architecture: A review. Annals of Botany, 87, 553-566.

Sokal RR, Rolhf FJ (1995). Biometry: The Principles and Practice of Statistics in Biological Research. 3rd edn. W. H. Freeman Company, New York.

Song CS (1997). Scientific Surver of Qingliangfeng Nature Reserve. China Forestry Publishing House, Beijing. (in Chinese) [宋朝枢 (1997). 浙江清凉峰自然保护区科学 考察集. 中国林业出版社, 北京.]

Sun SC, Jin DM, Shi PL (2006). The leaf size-twig size spectrum of temperate woody species along an altitudinal gradient: An invariant allometric scaling relationship. Annals of Botany, 97, 97-107.

Takenaka A (1994). Effects of leaf blade narrowness and petiole length on the light capture efficiency of a shoot. Ecological Research, 9, 109-114.

Taylor SE (1975). Optimal leaf form. In: Perspectives of Biophysical Ecology. Vol. 12. Springer, Berlin. 73-86.

Taylor SE, Sexton OJ (1972). Some implications of leaf tearing in Musaceae. Ecology, 53, 143-149.

Tomlinson PB (1987). Architecture of tropical plants. Annual Review of Ecology and Systematics, 18, 1-21.

Valladares F, Skillman JB, Pearcy RW (2002). Convergence in light capture efficiencies among tropical forest understory plants with contrasting crown architectures: A case of morphological compensation. American Journal of Botany, 89, 1275-1284.

Warton DI, Weber NC (2002). Common slope tests for bivariate errors-in-variables models. Biometrical Journal, 44, 161-174.

Warton DI, Wright IJ, Falster DS, Westoby M (2006). Bivariate line-fitting methods for allometry. Biological Reviews, 81, 259-291.

Westoby M, Falster DS, Moles AT, Vesk PA, Wright IJ (2002). Plant ecological strategies: Some leading dimensions of variation between species. Annual Review of Ecology and 
Systematics, 33, 125-159.

Westoby M, Wright IJ (2003). The leaf size-twig size spectrum and its relationship to other important spectra of variation among species. Oecologia, 135, 621-628.

Wright IJ, Reich PB, Westoby M, Ackerly DD, Baruch Z, Bongers F, Cavender-Bares J, Chapin T, Cornelissen JHC, Diemer M, Flexas J, Garnier E, Groom PK, Gulias J, Hikosaka K, Lamont BB, Lee T, Lee W, Lusk C, Midgley JJ, Navas ML, Niinemets U, Oleksyn J, Osada N, Poorter H, Poot P, Prior L, Pyankov VI, Roumet C, Thomas SC, Tjoelker MG, Veneklaas EJ, Villar R (2004). The worldwide leaf economics spectrum. Nature, 428, 821-827.

Wright IJ, Westoby M (2001). Understanding seedling growth relationships through specific leaf area and leaf nitrogen concentration: Generalisations across growth forms and growth irradiance. Oecologia, 127, 21-29.

Wright IJ, Westoby M, Reich PB (2002). Convergence towards higher leaf mass per area in dry and nutrient-poor habitats has different consequences for leaf life span. Journal of Ecology, 90, 534-543.

Yang DM, Li GY, Sun SC (2009). The effects of leaf size, leaf habit, and leaf form on leaf/stem relationships in plant twigs of temperate woody species. Journal of Vegetation
Science, 20, 359-366.

Yang DM, Niklas KJ, Xiang S, Sun SC (2010). Size-dependent leaf area ratio in plant twigs: Implication for leaf size optimization. Annals of Botany, 105, 71-77.

Yang DM, Zhang JJ, Zhou D, Qian MJ, Zheng Y, Jin LM (2012). Leaf and twig functional traits of woody plants and their relationships with environmental change: A review. Chinese Journal of Ecology, 31, 702-713. (in Chinese with English abstract) [杨冬梅, 章佳佳, 周丹, 钱敏杰, 郑瑶, 金灵妙 (2012). 木本植物茎叶功能性状及其关系 随环境变化的研究进展. 生态学杂志, 31, 702-713.]

Zhu JD, Meng TT, Ni J, Su HX, Xie ZQ, Zhang SR, Zheng YR, Xiao CW (2011). Within-leaf allometric relationships of mature forests in different bioclimatic zones vary with plant functional types. Chinese Journal of Plant Ecology, 35, 687-698. (in Chinese with English abstract) [祝介东, 孟婷婷, 倪健, 苏宏新, 谢宗强, 张守仁, 郑元润, 肖春 旺 (2011). 不同气候带间成熟林植物叶性状间异速生 长关系随功能型的变异. 植物生态学报, 35, 687-698.]

责任编委: 邓建明 责任编辑: 王 葳 